\title{
High-quality algae attached to leaf litter boost invertebrate shredder growth
}

\author{
Fen Guo ${ }^{1,2,4}$, Martin J. Kainz ${ }^{3,5}$, Dominic Valdez ${ }^{1,6}$, Fran Sheldon ${ }^{1,7}$, and Stuart E. Bunn ${ }^{1,8}$ \\ ${ }^{1}$ Australian Rivers Institute, Griffith University, 170 Kessels Road, Nathan, Queensland, 4111, Australia \\ ${ }^{2}$ State Key Laboratory of Environmental Criteria and Risk Assessment, Chinese Research Academy of Environmental Sciences, \\ 8 Dayangfang, Beiyuan, Anwai, Beijing 100012, People's Republic of China \\ ${ }^{3}$ WasserCluster Lunz - Inter-university Centre for Aquatic Ecosystem Research, Dr. Carl Kupelwieser Promenade 5, \\ A-3293 Lunz am See, Austria
}

\begin{abstract}
Algae are higher-quality food resources than allochthonous plant litter for stream invertebrates, in part, because of their higher content of polyunsaturated fatty acids (PUFAs). We tested the hypothesis that algal biofilms on the surfaces of leaf litter improve the nutritional quality of terrestrial inputs for invertebrate shredders. We used a laboratory feeding experiment with 2 light levels (open and shaded) and 2 nutrient regimes (ambient and enriched) to manipulate the algal biofilms that form on leaf surfaces (Lophostemon confertus). We assessed how these treatments affected the fatty acid (FA) composition of these biofilms and the somatic growth of a stream invertebrate shredder (Anisocentropus bicoloratus, Trichoptera) that feeds on the conditioned leaf litter. Shredders reached a significantly larger size when nutrients were added, and leaf mass loss was significantly greater in these treatments than in treatments without nutrients. Shredder growth was affected significantly by leaf PUFA content, and variations in shredder PUFA content were consistent with those in leaf PUFAs. Our results suggest that high-quality algae attached to leaf litter regulated the PUFA composition and improved the somatic growth of these shredders. Our data provide evidence that the availability of high-quality algae enhances dietary use of low-quality riparian leaf litter in stream food webs.
\end{abstract}

Key words: polyunsaturated fatty acids, riparian canopy, nutrients, allochthonous sources, autochthonous sources

The relative importance of allochthonous leaf litter and autochthonous algae for stream food webs has been debated for decades (Vannote et al. 1980, Junk et al. 1989, Bunn et al. 2003), but few investigators have considered the interaction between these 2 food sources and the consequent effect on their consumers. Leaf-litter conditioning by the heterotrophic microbial community (fungi and bacteria) is a major factor determining the fate of allochthonous material in food webs (Allan and Castillo 2007). However, algae on leaf surfaces can stimulate heterotrophic activity and increase leaf-litter decomposition and, thus, may improve the nutritional quality of leaf material for invertebrates (Danger et al. 2013, Kuehn et al. 2014).

Algae are much higher quality food than allochthonous leaf litter for stream invertebrates because they have a higher content of polyunsaturated fatty acids (PUFAs), in particular $\omega 3$ PUFAs (Torres-Ruiz et al. 2007, Lau et al. 2009). PUFAs are critical constituents for all biota in that they play an important role in regulating cell membrane fluidity and serve as precursors for animal hormones (Sargent et al. 1999). However, most aquatic consumers are unable or have limited ability to synthesize PUFAs de novo and must obtain PUFAs from their food sources (Brett and Müller-Navarra 1997). Diatoms and cryptophytes are considered high-quality food sources for aquatic invertebrates because they contain the long-chain $\omega 3$ PUFAs eicosapentaenoic acid (EPA; $20: 5 \omega-3)$ and docosahexaenoic acid (DHA; $22: 6 \omega-3$ ) (Brett and Müller-Navarra 1997). Cryptophytes also have high proportions of the short-chain $\omega 3$ PUFAs $\alpha$-linolenic acid (ALA; $18: 3 \omega-3$ ) and stearidonic acid (SDA; $18: 4 \omega 3$ ) (Brett et al. 2009). In contrast, higher plants often have a high proportion of saturated fatty acids (SAFAs), which are often used for energy storage and are preferentially catabolized by animals (Brett et al. 2009). Fungi and bacteria colonizing decomposing leaves can increase the nutritional quality of leaf litter by decreasing $\mathrm{C}: \mathrm{N}$ ratios and increasing protein content (Suberkropp 2001, Manning et al. 2015, Guo et al. 2016b). Nevertheless, this

E-mail addresses: ${ }^{4}$ fen.guo@griffithuni.edu.au; ${ }^{5}$ martin.kainz@donau-uni.ac.at; ${ }^{6}$ d.valdez@griffith.edu.au; ${ }^{7}$ f.sheldon@griffith.edu.au; ${ }^{8}$ s.bunn@griffith.edu.au

DOI: 10.1086/688667. Received 25 February 2016; Accepted 13 June 2016; Published online 9 August 2016.

Freshwater Science. 2016. 35(4):1213-1221. ๑ 2016 by The Society for Freshwater Science.

1213 
matrix of leaf-material fungi and bacteria lacks $\omega 3$ PUFAs because fungi are characterized by $16: 0,18: 0,18: 1 \omega 9$, and LIN according to studies done in terrestrial and marine ecosystems (Cooney et al. 1993, Stahl and Klug 1996) and bacteria are generally rich in 15:0, 17:0 and their branched derivatives, and vaccenic acid $(18: 1 \omega 7)$ (Desvilettes et al. 1997, Kainz and Mazumder 2005). Therefore, the presence of high-quality algae attached to leaf litter probably provides physiologically important $\omega 3$ PUFAs for aquatic invertebrates.

Algal PUFA content is sensitive to environmental conditions (Guschina and Harwood 2009, Guo et al. 2015). Few authors have referred specifically to the PUFA content of algae attached to terrestrial leaf litter, but in studies on phytoplankton and periphyton, low light levels generally result in higher PUFA content, whereas high light levels lead to lower PUFA content (Guschina and Harwood 2009). Nutrient limitation leads to increasing cellular production of triacylglycerols (TAG) and decreasing proportions of PUFAs in most algae, whereas greater aqueous nutrient levels cause an increase in PUFA content (Guschina and Harwood 2009, Guo et al. 2016a). Light intensity and nutrient enrichment positively affect algal abundance and production on leaf surfaces (Franken et al. 2005, Albarino et al. 2008, Danger et al. 2013, Kuehn et al. 2014). To date, few studies have considered the combined effect of light and nutrients on algae attached to leaf litter and their consequent effect on invertebrate consumers.

In stream ecosystems, macroinvertebrate shredders are responsible for up to $70 \%$ of the leaf-litter processing (Cuffney et al. 1990). Invertebrate shredders selectively choose conditioned over fresh detritus (Nolen and Pearson 1993, Connolly and Pearson 2013), and select more nutritious leaves or patches on leaves by discriminating among leaf species and decomposition stages (Clapcott and Bunn 2003, Leberfinger and Bohman 2010, Fuller et al. 2015). The nutritional function of fungi and bacteria on leaf litter for shredder growth has been widely studied, especially for fungi as the pioneer microbial decomposers (Hieber and Gessner 2002). Benthic algae often are found on submerged leaf litter and are thought to be an important component of the leaf biofilm for invertebrates (Franken et al. 2005, Albarino et al. 2008), but the nutritional importance of algal biofilms for invertebrate shredders has yet to be reported.

Therefore, we conducted an experimental study in which we used different light and nutrient levels to assess the effect of PUFA content of algae attached to leaf litter on the somatic growth of stream invertebrate shredders. Preliminary examination of algal communities attached to leaf surfaces in our study showed that cyanobacteria, diatoms, cryptophytes, and green algae were present. Fungi also were observed. Therefore, we used $\omega 3$ PUFAs as a biomarker of high-quality algae, the sum of bacterial fatty acids (BAFAs) as a biomarker of bacteria, the sum of long- chain SAFAs (i.e., $20: 0,22: 0$ and 24:0) as a biomarker of terrestrial $\mathrm{C}$ (terrFA), and $16: 1 \omega 7$ as a biomarker of diatoms (Napolitano et al. 1994, Torres-Ruiz et al. 2007) to explore the nutritional role of high-quality algae attached to leaf litter in invertebrate shredder growth. In addition to high proportions of long-chain SAFAs, living terrestrial leaf matter of vascular plants also contains relatively high levels of C18 PUFAs (i.e., LIN and ALA) but nondetectable highly unsaturated fatty acids (i.e., EPA and DHA) (Napolitano 1999, Mills et al. 2001). However, C18 PUFAs usually are lost when leaves are dead (Torres-Ruiz et al. 2010). We used only dead submerged leaf litter in our study. Therefore, only long-chain SAFAs were used as the biomarker of terrestrial matter. We tested the hypotheses that: 1 ) nutrient enrichment would result in a greater content of $\omega 3$ PUFAs in leaf litter, and consequently increase shredder growth, and 2) open canopy (high light intensity) would lead to a lower content of $\omega 3$ PUFAs in leaf litter, which in turn would restrict shredder growth.

\section{METHODS}

\section{Experimental design}

We established 2 light levels (open and shade) and 2 nutrient regimes (ambient and enriched) in a $2 \times 2$ factorial design, resulting in 4 treatments, i.e., open canopy without added nutrients $(\mathrm{O})$, open canopy with added nutrients $(\mathrm{O}+\mathrm{N})$, shade canopy without added nutrients $(\mathrm{S})$, and shade canopy with added nutrients $(\mathrm{S}+\mathrm{N})$. We conducted the experiments in individual aerated plastic containers filled with $700 \mathrm{~mL}$ of either natural stream water or nutrientenriched stream water. We used 6 replicates of each treatment with invertebrate shredders to assess the effect of algal PUFAs in leaf litter on shredder growth, 4 replicates without shredders as controls to evaluate the effect of leaf leaching on measured variables, and 3 replicates of each treatment without shredders to estimate the treatment effect on algal community composition attached to leaf surfaces.

We collected invertebrate shredders, Anisocentropus bicoloratus, (Trichoptera) and leaf litter from Lophostemon confertus (brush box) from a 25-m riffle in Stony Creek, a $4^{\text {th }}$-order forested stream in the Brisbane River catchment in southeastern Queensland, Australia. The climate in this area is subtropical humid with hot wet summers and mild dry winters and an average annual rainfall of $1500 \mathrm{~mm}$ (Clapcott and Bunn 2003). The major vegetation is dense, wet sclerophyll rain forest (Clapcott and Bunn 2003), and Lophostemon confertus is one of the abundant tree species in this area. Submerged leaves of this species were collected randomly from the stream bottom. The color of submerged leaves ranged from green, brown, red-brown, to dark. Green leaves were those that had fallen into the stream most recently. Dark leaves were almost completely decomposed and were easily broken. We collected the brown and red-brown 
leaves and took them to the laboratory. Before the feeding experiment, we did an initial test to determine which type of leaf was preferred by the shredders. Most shredders chose the red-brown leaves, and thus, we used this type of leaf in the feeding experiment. We picked individuals of Anisocentropus bicoloratus from submerged leaf litter in streams and held them in stream water. The genus Anisocentropus is the only Australian representative of the family Calamoceratidae (sleeping bag caddis with the cases made from 2 leaf fragments) (Gooderham and Tsyrlin 2002), and they are the most abundant shredders of allochthonous leaf litter in the study area (Clapcott and Bunn 2003).

In the laboratory, we punched leaf disks $(19.0 \mathrm{~mm}$ diameter) from the leaves, avoiding the midrib of each leaf, and blotted disks with Kimwipes ${ }^{\mathrm{TM}}$ to remove sediment from their surface. We estimated initial dry mass (DM) of leaf disks by regression analysis of wet vs freeze-dried mass of 40 replicate disks $\left(y=0.99 x-45.2, R^{2}=0.94\right)$. Meanwhile, we acclimatized the shredder larvae in the laboratory for $7 \mathrm{~d}$ before the feeding experiment in aerated stream water with a diet solely of conditioned Lophostemon confertus. We established a regression between ventral case length and freeze-dried mass with 80 replicate individuals $\left(y=0.27 x-1.42, R^{2}=0.90\right)$. Larval ventral case length ranged from 5.0 to $13.0 \mathrm{~mm}$, and pupae were found in cases with ventral case length from 12.0 to $15.0 \mathrm{~mm}$. We used larvae with the same ventral case length $(9.0 \mathrm{~mm})$, which was the most abundant size group among all larvae, in the feeding experiment.

We used 4 metal halide lights $(10000 \mathrm{~K}, 150 \mathrm{~W}$; Abyss Aquarium, Sydney, Australia) to obtain the open-canopy treatment and $90 \%$ shade cloth under these lights to obtain the shade-canopy treatment. We checked light intensity at the water surface of each container with a light meter (LIN-250A; LI-COR, Lincoln, Nebraska) every other day. The light intensity was $114.13 \pm 3.78 \mu \mathrm{mol} \mathrm{m} \mathrm{m}^{-2} \mathrm{~s}^{-1}$ (mean $\pm \mathrm{SE})$ in the open-canopy treatments and $21.13 \pm$ $1.01 \mu \mathrm{mol} \mathrm{m} \mathrm{m}^{-2} \mathrm{~s}^{-1}$ in the shade-canopy treatments. We made enriched nutrient solutions by adding $\mathrm{N}$ as $\mathrm{NaNO}_{3}$ and $\mathrm{P}$ as $\mathrm{KH}_{2} \mathrm{PO}_{4}$ to stream water. The ambient $\mathrm{NO}_{\mathrm{x}}$ concentration in Stony Creek was $0.02 \mathrm{mg} \mathrm{N} / \mathrm{L}$, and soluble reactive $\mathrm{P}(\mathrm{SRP})$ was $0.012 \mathrm{mg} \mathrm{P} / \mathrm{L}$ with an $\mathrm{N}: \mathrm{P}$ ratio of 1.67. The enriched NOx concentration was $1.08 \pm 0.01 \mathrm{mg}$ $\mathrm{N} / \mathrm{L}$, and SRP was $0.66 \pm 0.00 \mathrm{mg} \mathrm{P} / \mathrm{L}$ with an $\mathrm{N}: \mathrm{P}$ ratio of 1.63. The $\mathrm{NH}_{4}-\mathrm{N}$ concentrations of both ambient and enriched water were below the detection limit $(0.01 \mathrm{mg} \mathrm{N} / \mathrm{L})$.

We put 50 leaf disks (mean $\mathrm{DM}=3126.4 \pm 0.4 \mathrm{mg}$ ) in each container with 10 shredders, and 1 leaf disk in each container without shredders. We assigned the 4 treatments randomly across containers. We applied a photoperiod of $12: 12 \mathrm{~h}$ light:dark and monitored water temperature throughout the experiment. We replaced either stream water or enriched nutrient water every $6 \mathrm{~d}$. The experiment lasted 17 d from 12-28 August 2015.

\section{Sample collection}

After the experiment, we collected leaf litter for fatty acid (FA) analysis from each container and placed it in a $-80^{\circ} \mathrm{C}$ freezer. We kept leaf litter for algal taxonomic identification in Lugol's iodine preservative and in the dark without refrigeration. We sampled invertebrate shredders carefully with their cases to keep their bodies intact, put each shredder in an individual vial, and immediately placed the vial in a $-80^{\circ} \mathrm{C}$ freezer. Larval survival was high throughout the experiment, and we observed no mortality. Five larvae began to pupate during the experiment ( 2 in $\mathrm{S}+\mathrm{N}$ and 3 in $\mathrm{O}+\mathrm{N})$, so these specimens were not included in the analysis.

\section{Sample processing}

We scrubbed algae gently off from the leaf surface with a spatula. We loaded a 1-mL subsample on a SedgwickRafter counting chamber for identification and enumeration under a light microscope (Leica DM4000; Leica, Wetzlar, Germany). We identified algae to the genus level at $400 \times$ magnification and stopped enumeration on a /cell basis when the most common taxon had a minimum of 23 units (trichomes, filaments, or colonies) or 40 squares had been counted on the counting chamber (Hötzel and Croome 1999). The enumeration step was followed by examining the slide at $200 \times$ magnification for 200 squares of the counting chamber to identify algal taxa that were not previously observed (Entwisle et al. 1997).

We freeze-dried all samples for FA analysis (VirTis Genesis Freeze Dryer; VWR International, Murarrie, Australia). We measured DM of leaf litter, and then homogenized the leaf litter to powder. We used $150 \mathrm{mg} \mathrm{DM} /$ sample for FA analysis. The DM of each shredder (without case) was measured on a microbalance (weighing capacity $=5.10 \mathrm{mg}$; Sartorius, Göttingen, Germany) and shredders from the same container were pooled. In total, we prepared 24 samples with a DM of $10 \mathrm{mg} / \mathrm{sample}$ for FA analysis. We extracted lipids according to a modified version of the methods presented by Kainz et al. (2010). Briefly, leaf litter or shredder samples were extracted in chloroform: methanol ( $2: 1$ volume/volume), and then the solution was sonicated, vortexed, and centrifuged 3 times to remove nonlipid materials. We used nonadecanoic acid (19:0) as an internal standard. Extracted lipids were evaporated to a final volume $(1.5 \mathrm{~mL})$ under $\mathrm{N}_{2}$. We dispensed duplicate aliquots $(100 \mu \mathrm{L}$ each) into preweighed $\mathrm{Sn}$ cups for gravimetric assessment of total lipid content and stored the remaining extract at $-20^{\circ} \mathrm{C}$ until the FAs were derivatized to FA methyl esters (FAMEs). For FAME formation, we used sulfuric acid in methanol (1:100 mixture) as the methylation reagent, added toluene to the lipid extract, and incubated the solution for $16 \mathrm{~h}$ at $50^{\circ} \mathrm{C}$ in a water bath. Thereafter, potassium hydrogen carbonate and hexane were added, followed by shaking, vortexing, and centrifu- 
gation. We transferred the upper organic layer of the solution and added hexane again. We repeated this step twice. All layers containing FAME were pooled and concentrated under $\mathrm{N}_{2}$. FAs were analyzed as FAME on a gas chromatograph (Thermo Trace GC; Thermo Fisher Scientific, Waltham, Massachusetts; Heissenberger et al. 2010), identified by comparison of their retention times with known standards (37-component FAME mix, 47885-U, Supelco; Sigma-Aldrich, Bellefonte, Pennsylvania), and then quantified using 7-point calibration curves based on known standard concentrations ( $\mu \mathrm{g}$ FAME/mg DM).

\section{Data analysis}

We evaluated the effects of light and nutrients on algal community composition, FA contents of leaf litter or shredders, and leaf mass loss or shredder growth with 2way analysis of variance (ANOVA). We conducted multiple linear regressions to explore the relationships between shredder growth and leaf FA biomarkers. In addition, we assessed the relationship between leaf $\omega 3$ PUFAs and BAFAs in each treatment by correlation analysis. Data were $\log _{10}(x)$-transformed to approximate a normal distribution except that algal community composition data were $\sqrt{ }(x)$-transformed. We conducted all statistical analyses in R (version 3.0.3; R Project for Statistical Computing, Vienna, Austria).

\section{RESULTS}

\section{Variations in algal community composition on leaf surfaces}

Algal community composition was dominated by cyanobacteria across the 4 treatments (Table 1 ). The proportion of cyanobacteria decreased and the proportion of diatoms increased as nutrients were added regardless of light intensity. The proportion of green algae increased with nutrient enrichment and light, but the light $\times$ nutrient interaction was not significant.

\section{Variations in leaf FA content}

The content of total FA and FA groups, i.e., total SAFA and total monounsaturated fatty acids (MUFAs), did not change in response to light and nutrients (Table 2). The combined effect of shade (negative) and added nutrients (positive) resulted in a significant increase of total PUFAs.

The content of individual PUFAs were significantly altered by light and nutrients (Table 2). DHA, ARA, and ALA increased with nutrient enrichment, and LIN content increased with the interaction of shade and added nutrients.

The responses of FA biomarker content to light and nutrients were FA specific (Table 2). Nutrient enrichment increased $\omega 3$ PUFAs and $16: 1 \omega 7$. BAFA content increased with added nutrients and with the interaction of shade and added nutrients. The $\omega 3: \omega 6$ ratio was positively affected by light and nutrients, with the lowest value in the $\mathrm{O}$ treatment (open canopy without nutrient addition). However, light and nutrients did not affect terrFA content.

The correlation between $\omega 3$ PUFAs and BAFAs was significant in the $\mathrm{S}$ treatment $(r=0.83, p=0.04)$, and nearly significant in the $\mathrm{O}$ treatment (open canopy without nutrient addition, $r=0.79, p=0.06)$, but not significant in the nutrient-enriched treatments $(\mathrm{O}+\mathrm{N}, r=-0.44$, $p=0.38 ; \mathrm{S}+\mathrm{N}, r=0.06, p=0.91)$.

\section{Shredder FA and growth}

Light and nutrients did not lead to pronounced changes in the content of total FA and FA groups (total SAFA, total MUFA, and total PUFA) (Table 3), but did affect some individual PUFA and FA biomarkers in shredder body tis-

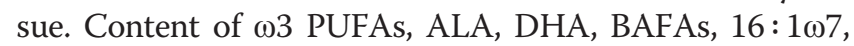
and the $\omega 3: \omega 6$ ratio increased as nutrients were added and showed no changes in response to light treatments or the interaction of light and nutrients. However, terrFA content decreased with nutrient enrichment and increased with shade.

The first multiple linear regression based on all leaflitter FA biomarkers ( $\omega 3$ PUFAs, 16:1 $1 \omega 7$, terrFA, and BAFAs) as predictor variables of shredder growth showed that shredder growth was affected by the content of leaf FA biomarkers and accounted for $65 \%$ of the vari-

Table 1. Means $( \pm$ SE) and analysis of variance (ANOVA) of light and nutrient effects on $\sqrt{ }(x)$-transformed algal community composition. $\mathrm{O}=$ open canopy without added nutrients, $\mathrm{O}+\mathrm{N}=$ open canopy with added nutrients, $\mathrm{S}=$ shade without added nutrients, $\mathrm{S}+\mathrm{N}=$ shade with added nutrients. ${ }^{*}=p<0.05,{ }^{* * * *}=p<0.01,{ }^{* * * * *}=p<0.001$.

\begin{tabular}{|c|c|c|c|c|c|c|c|}
\hline \multirow[b]{2}{*}{ Algal group } & \multicolumn{4}{|c|}{ Proportional abundance } & \multicolumn{3}{|c|}{ ANOVA $(F$ value, $\mathrm{df}=1)$} \\
\hline & $\mathrm{O}$ & $\mathrm{O}+\mathrm{N}$ & $S$ & $\mathrm{~S}+\mathrm{N}$ & Light & Nutrients & Light $\times$ nutrients \\
\hline Cyanobacteria & $0.984 \pm 0.010$ & $0.488 \pm 0.173$ & $0.987 \pm 0.006$ & $0.737 \pm 0.080$ & & $9.44^{*}$ & \\
\hline Diatoms & $0.014 \pm 0.008$ & $0.437 \pm 0.143$ & $0.012 \pm 0.006$ & $0.253 \pm 0.081$ & & $43.70 \% * *$ & \\
\hline Green algae & $0.001 \pm 0.001$ & $0.073 \pm 0.030$ & $0.000 \pm 0.000$ & $0.010 \pm 0.008$ & $7.30^{*}$ & $19.17^{* * *}$ & \\
\hline Cryptomonads & $0.002 \pm 0.002$ & $0.002 \pm 0.001$ & $0.001 \pm 0.000$ & $0.000 \pm 0.000$ & & & \\
\hline
\end{tabular}


Table 2. Means ( \pm SE, $n=6$ ) and analysis of variance (ANOVA) of light and nutrient effects on the $\log (x)$-transformed content of leaf-litter fatty acid (FA) groups, essential FAs, and FA biomarkers. SAFA = saturated FAs, MUFA = monounsaturated FAs, PUFA = polyunsaturated FAs, EPA = eicosapentaenoic acid $(20: 5 \omega-3)$, DHA $=$ docosahexaenoic acid $(22: 6 \omega-3)$, ARA = arachidonic acid

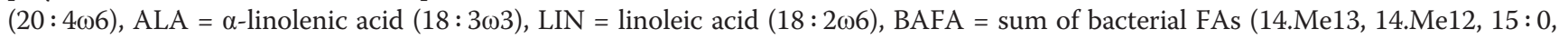

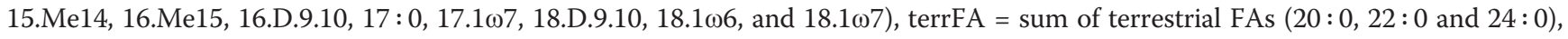
$\mathrm{O}=$ open canopy without added nutrients, $\mathrm{O}+\mathrm{N}=$ open canopy with added nutrients, $\mathrm{S}=$ shade without added nutrients, $\mathrm{S}+\mathrm{N}=$ shade with added nutrients, $\mathrm{DM}=$ dry mass. ${ }^{*}=p<0.05,{ }^{* * *}=p<0.01,{ }^{* * * *}=p<0.001$.

\begin{tabular}{|c|c|c|c|c|c|c|c|}
\hline \multirow[b]{2}{*}{ FAs } & \multicolumn{4}{|c|}{ FA content ( $\mu \mathrm{g}$ FAME/mg DM) } & \multicolumn{3}{|c|}{ ANOVA $(F$ value, $\mathrm{df}=1)$} \\
\hline & $\mathrm{O}$ & $\mathrm{O}+\mathrm{N}$ & S & $\mathrm{S}+\mathrm{N}$ & Light & Nutrients & Light $\times$ nutrients \\
\hline Total FA & $2.773 \pm 0.047$ & $2.772 \pm 0.128$ & $2.124 \pm 0.347$ & $2.843 \pm 0.112$ & & & \\
\hline SAFA & $1.472 \pm 0.033$ & $1.527 \pm 0.077$ & $1.129 \pm 0.179$ & $1.517 \pm 0.054$ & & & \\
\hline MUFA & $0.504 \pm 0.006$ & $0.453 \pm 0.022$ & $0.396 \pm 0.077$ & $0.470 \pm 0.027$ & & & \\
\hline PUFA & $0.768 \pm 0.015$ & $0.760 \pm 0.039$ & $0.575 \pm 0.090$ & $0.817 \pm 0.041$ & & & $4.70^{*}$ \\
\hline EPA & $0.015 \pm 0.001$ & $0.014 \pm 0.002$ & $0.010 \pm 0.002$ & $0.016 \pm 0.002$ & & & \\
\hline DHA & $0.005 \pm 0.001$ & $0.005 \pm 0.000$ & $0.004 \pm 0.001$ & $0.007 \pm 0.001$ & & $5.42 \%$ & \\
\hline ARA & $0.009 \pm 0.000$ & $0.010 \pm 0.001$ & $0.007 \pm 0.001$ & $0.011 \pm 0.001$ & & $7.92 \%$ & \\
\hline ALA & $0.349 \pm 0.008$ & $0.372 \pm 0.020$ & $0.286 \pm 0.050$ & $0.400 \pm 0.026$ & & $5.35^{*}$ & \\
\hline LIN & $0.333 \pm 0.008$ & $0.310 \pm 0.016$ & $0.227 \pm 0.033$ & $0.324 \pm 0.014$ & & & $6.37^{* * *}$ \\
\hline$\omega 3$ PUFA & $0.375 \pm 0.009$ & $0.401 \pm 0.022$ & $0.307 \pm 0.052$ & $0.436 \pm 0.029$ & & $5.94 \%$ & \\
\hline BAFA & $0.131 \pm 0.006$ & $0.126 \pm 0.005$ & $0.090 \pm 0.019$ & $0.159 \pm 0.012$ & & $5.39 \%$ & $6.82^{*}$ \\
\hline terrFA & $0.211 \pm 0.004$ & $0.208 \pm 0.010$ & $0.158 \pm 0.024$ & $0.213 \pm 0.008$ & & & \\
\hline $16: 1 \omega 7$ & $0.042 \pm 0.003$ & $0.062 \pm 0.004$ & $0.035 \pm 0.007$ & $0.062 \pm 0.004$ & & $13.78^{* * * * *}$ & \\
\hline$\omega 3: \omega 6$ & $0.920 \pm 0.020$ & $1.119 \pm 0.026$ & $1.125 \pm 0.043$ & $1.122 \pm 0.050$ & $7.20 \%$ & $5.03^{*}$ & \\
\hline
\end{tabular}

ation in shredder growth $(p<0.001)$. Leaf $\omega 3$ PUFAs and $16: 1 \omega 7$ both increased shredder growth $(p=0.03$ and $p=0.01$, respectively), whereas terrFA was negatively related to shredder growth $(p=0.003)$. Leaf BAFA content had no significant effect on shredder growth $(p=0.53)$. A second multiple linear regression based only on algal biomarkers as the predictor of shredder growth showed that the high-quality algal biomarkers ( $\omega 3$ PUFAs and $16: 1 \omega 7)$ explained $43 \%$ of the variation in shredder growth $(p=$ $0.003)$.

Nutrient enrichment led to a significant increase in shredder DM regardless of light intensity $(p<0.001, F=$ 115.44; Fig. 1). Nutrient-enriched treatments $(\mathrm{O}+\mathrm{N}$ and $\mathrm{S}+\mathrm{N}$ ) were associated with larger shredder size and greater content of $\omega 3$ PUFAs, ALA, DHA, BAFA, and $16: 1 \omega 7$ in the conditioning leaf litter. In contrast, smaller shredder size and lower content of the above FAs on leaves were associated with the $\mathrm{S}$ treatment. In the $\mathrm{O}$ treatment, the content of these FAs were between those of $\mathrm{S}$ and $\mathrm{S}+\mathrm{N}$, but were associated with smaller shredder size.

\section{Leaf mass loss}

Leaf mass loss was higher with than without nutrient addition ( $p<0.001, F=95.59)$ (Fig. 2) but did not differ between light treatments. The regression relationship be- tween leaf mass loss and shredder growth was significant $\left(R^{2}=0.91, p<0.001\right)$.

\section{DISCUSSION}

Our results suggest that high-quality algae attached to leaf litter boosted invertebrate shredder growth. The studied shredder, A. bicoloratus, obtained most of its energy by leaf consumption, but these organisms acquired and selectively retained their physiologically important FA from high-quality algae. Our study provides evidence that the availability of high-quality algae regulates invertebrate shredder growth and incorporation of low-quality leaf litter into aquatic food webs in stream ecosystems (Franken et al. 2005, Brett et al. 2009). In our study, enriched nutrients led to an increase in leaf-litter $\omega 3$ PUFA content and rendered the leaf litter more nutritious for invertebrate shredders, which in turn enhanced shredder growth.

The total FA content was $\sim 12$ to $15 \times$ higher in shredder body tissue than in leaf litter, indicating the nutritional importance of dietary lipids. The increases in content of $\omega 3$ PUFAs, DHA, ALA, and the diatom biomarker $16: 1 \omega 7$ in shredder body tissue as nutrients were added were consistent with changes in the leaf FA content. The FA composition of the stream net-spinning caddisfly larvae Hydropsyche sp. also varied with their food sources (Torres-Ruiz et al. 2010). Pearson and Connolly 
Table 3. Means ( \pm SE, $n=6$ ) and analysis of variance (ANOVA) of light and nutrient effects on the $\log (x)$-transformed content of shredder fatty acid (FA) groups, essential FAs, and FA biomarkers. SAFA = saturated FAs, MUFA = monounsaturated FAs, PUFA = polyunsaturated FAs; EPA $=$ eicosapentaenoic acid $(20: 5 \omega-3)$, DHA $=$ docosahexaenoic acid $(22: 6 \omega-3)$, ARA = arachidonic acid $(20: 4 \omega 6)$, ALA $=\alpha$-linolenic acid $(18: 3 \omega 3)$, LIN $=$ linoleic acid $(18: 2 \omega 6)$, BAFA $=$ sum of bacterial FAs $(14 . M e 13,14 . M e 12,15: 0$,

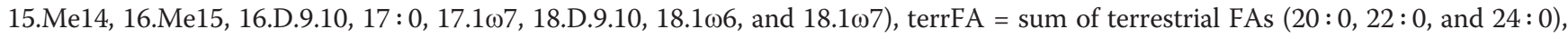
$\mathrm{O}=$ open canopy without added nutrients, $\mathrm{O}+\mathrm{N}=$ open canopy with added nutrients, $\mathrm{S}=$ shade without added nutrients, $\mathrm{S}+\mathrm{N}=$ shade with added nutrients, $\mathrm{DM}=$ dry mass. ${ }^{*}=p<0.05,{ }^{* * *}=p<0.01,{ }^{* * * * *}=p<0.001$.

\begin{tabular}{|c|c|c|c|c|c|c|c|}
\hline \multirow[b]{2}{*}{ FAs } & \multicolumn{4}{|c|}{ FA content ( $\mu \mathrm{g}$ FAME/mg DM) } & \multicolumn{3}{|c|}{ ANOVA $(F$ value, $\mathrm{df}=1)$} \\
\hline & $\mathrm{O}$ & $\mathrm{O}+\mathrm{N}$ & S & $\mathrm{S}+\mathrm{N}$ & Light & Nutrients & Light $\times$ nutrients \\
\hline Total FA & $32.996 \pm 2.765$ & $33.588 \pm 2.139$ & $32.017 \pm 2.517$ & $38.513 \pm 1.539$ & & & \\
\hline SAFA & $9.721 \pm 1.058$ & $10.513 \pm 0.734$ & $9.571 \pm 0.859$ & $12.277 \pm 0.632$ & & & \\
\hline MUFA & $8.026 \pm 0.810$ & $7.786 \pm 0.584$ & $7.684 \pm 0.683$ & $8.888 \pm 0.365$ & & & \\
\hline PUFA & $14.332 \pm 0.831$ & $14.092 \pm 0.769$ & $13.951 \pm 0.916$ & $16.056 \pm 0.554$ & & & \\
\hline EPA & $1.137 \pm 0.043$ & $1.028 \pm 0.044$ & $1.224 \pm 0.089$ & $1.111 \pm 0.032$ & & & \\
\hline DHA & $0.009 \pm 0.001$ & $0.010 \pm 0.001$ & $0.006 \pm 0.000$ & $0.010 \pm 0.001$ & & $4.56^{*}$ & \\
\hline ARA & $0.551 \pm 0.017$ & $0.545 \pm 0.032$ & $0.598 \pm 0.027$ & $0.560 \pm 0.015$ & & & \\
\hline ALA & $4.986 \pm 0.436$ & $5.359 \pm 0.280$ & $4.912 \pm 0.416$ & $6.420 \pm 0.362$ & & $6.11^{*}$ & \\
\hline LIN & $7.400 \pm 0.461$ & $6.908 \pm 0.436$ & $6.973 \pm 0.420$ & $7.665 \pm 0.257$ & & & \\
\hline$\omega 3$ PUFA & $6.210 \pm 0.423$ & $6.475 \pm 0.304$ & $6.209 \pm 0.500$ & $7.628 \pm 0.346$ & & $4.62^{*}$ & \\
\hline BAFA & $2.382 \pm 0.216$ & $3.075 \pm 0.187$ & $2.274 \pm 0.197$ & $3.377 \pm 0.142$ & & $19.44^{* * * *}$ & \\
\hline terrFA & $0.281 \pm 0.003$ & $0.227 \pm 0.013$ & $0.298 \pm 0.015$ & $0.259 \pm 0.009$ & $4.77^{*}$ & $17.17^{* * * *}$ & \\
\hline $16: 1 \omega 7$ & $0.465 \pm 0.029$ & $0.712 \pm 0.06$ & $0.540 \pm 0.132$ & $0.680 \pm 0.045$ & & $9.80 * *$ & \\
\hline$\omega 3: \omega 6$ & $0.764 \pm 0.029$ & $0.854 \pm 0.016$ & $0.799 \pm 0.034$ & $0.904 \pm 0.028$ & & $12.86^{* *}$ & \\
\hline
\end{tabular}

(2000) suggested that Anisocentropus sp. could assimilate more lipids from available leaf material when nutrients were supplemented. In our study, the content of total SAFAs, total MUFAs, and total PUFAs in shredder body tissue did not change as nutrients were enriched, but content of $\omega 3$ PUFAs, DHA, and ALA increased significantly. This finding suggests that Anisocentropus can selectively retain physiologically important FA for their somatic growth. The increased content of these FAs in shredder body tissue revealed increased ingestion or assimilation of high-quality algae.

Variations in shredder FA content were reflected in their somatic growth, and shredders reached a larger size in the nutrient-enriched treatments. $\omega 3$ PUFAs from highquality algae can enhance invertebrate somatic growth and reproduction (Müller-Navarra et al. 2000, Wacker and von Elert 2001) and can stimulate energy-transfer efficiency to upper trophic levels (Kainz et al. 2004, Gladyshev et al. 2011). Total FA content in leaf litter was very low (Cargill et al. 1985) and accounted for only $1.6 \pm 0.1 \%(n=24)$ of leaf DM, but shredders acquired and selectively retained $\omega 3$ PUFAs. Increased nutrient levels led to increases in shredder size and $\omega 3$ PUFA content but decreases in terrFA content, results suggesting that terrestrial $\mathrm{C}$ may be preferentially catabolized, whereas autochthonous algae play an important role in invertebrate somatic growth and reproduction (Brett et al. 2009).
The fact that shade ( $\mathrm{S}$ treatment) led to an increase in shredder terrFA content but was associated with smaller body size reflects the low nutritional quality of terrestrial C. A positive correlation between $\omega 3$ PUFA and BAFA was observed in the $S$ treatment, which may indicate a

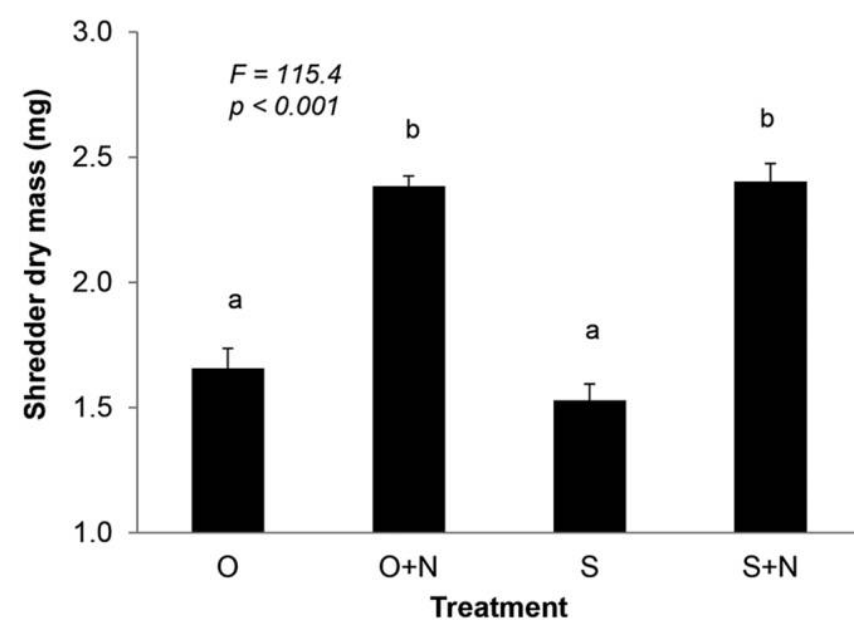

Figure 1. Mean (+SE) invertebrate shredder dry mass (DM) in response to light and nutrient treatments $(\mathrm{O}=$ open canopy without added nutrients, $\mathrm{O}+\mathrm{N}=$ open canopy with added nutrients, $\mathrm{S}=$ shade without added nutrients, $\mathrm{S}+\mathrm{N}=$ shade with added nutrients). Bars with the same letter are not significantly different $(p>0.05)$. 


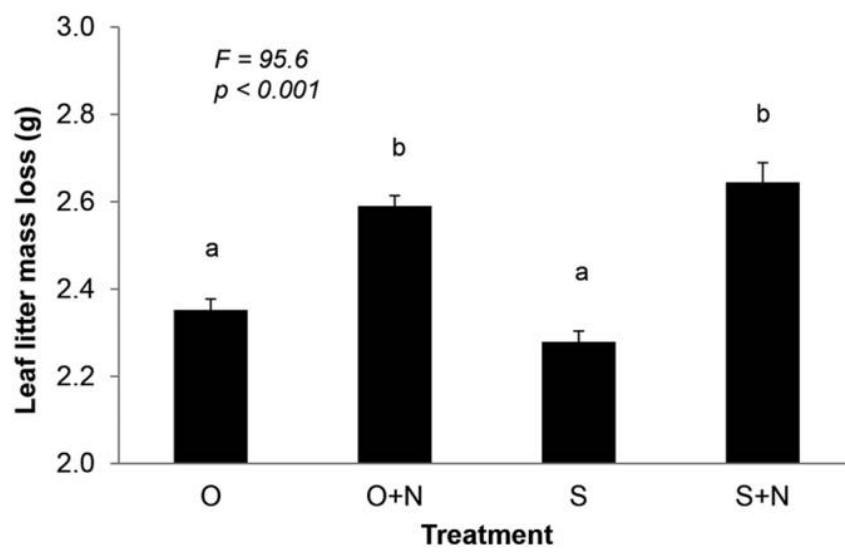

Figure 2. Mean $(+\mathrm{SE})$ invertebrate leaf-litter mass loss in response to light and nutrient treatments $(\mathrm{O}=$ open canopy without added nutrients, $\mathrm{O}+\mathrm{N}=$ open canopy with added nutrients, $\mathrm{S}=$ shade without added nutrients, $\mathrm{S}+\mathrm{N}=$ shade with added nutrients). Bars with the same letter are not significantly different $(p>0.05)$.

priming effect mediated by algae (Danger et al. 2013, Kuehn et al. 2014). Nutrient limitation can stimulate the production of C exudates by algae (Scott et al. 2008), which constitute an important $C$ source for bacteria (Rier et al. 2014). Terrestrial dissolved organic matter [DOM]driven bacterial production or recalcitrant terrestrial $C$ barely support zooplankton growth and reproduction, with low growth rates and very low numbers of viable offspring compared with zooplankton feeding on algae (Brett et al. 2009, McMeans et al. 2015). These findings are supported by our data that leaf BAFA concentration did not affect shredder growth. Given that leaf-litter $\omega 3$ PUFA content was very low in the $S$ treatment, shredders may have had to consume increased quantities of low-quality leaf litter to sustain somatic growth. Therefore, in our study, the smaller body size of invertebrate shredders in the $\mathrm{S}$ treatment could be attributed to low leaf $\omega 3$ PUFA content and the increased consumption of leaf litter.

Franken et al. (2005) found that open canopies led to increased shredder growth, but the $\mathrm{O}$ treatment in our study was associated with smaller shredder size. This result could be a consequence of the lower $\omega 3: \omega 6$ ratios of the leaf litter in the $\mathrm{O}$ than in the other treatments. Food sources with lower $\omega 3: \omega 6$ ratios could restrict invertebrate somatic growth and reproduction (Ahlgren et al. 2009). As reported in other studies, food sources with very low $\omega 3: \omega 6$ ratios gave only slightly lower growth rates of stream invertebrates than did the food with the much higher $\omega 3: \omega 6$ ratios (Goedkoop et al. 2007). $\omega 6$ PUFAs are found mainly in green algae, cyanobacteria, or fungi (Stahl and Klug 1996, Brett et al. 2009). Cyanobacteria were the most abundant algal group on leaf surfaces in our study. They typically lack long-chain PUFAs (Napolitano et al. 1994, Napolitano 1999) and negatively affect herbivore survival, population growth, and neonate size (Sarnelle et al. 2010).
The effect of fungi on invertebrate growth depends on different fungal assemblages (Cornut et al. 2015), and fungal growth and production may be stimulated by algae under open-canopy conditions (Kuehn et al. 2014). The high abundance of low-quality algae contributed to smaller shredder size in the $\mathrm{O}$ treatment. However, previous work by Franken et al. (2005) suggested that open canopy led to increased shredder growth because of higher algal biomass and a composition consisting of more diatoms and less green algae. Combined with their findings, our results suggest that high-quality diatoms, rather than all algae, attached to leaf litter can stimulate shredder growth.

In addition to variation in FA composition, leaf mass loss increased significantly when nutrients were added $(\mathrm{O}+\mathrm{N}$ and $\mathrm{S}+\mathrm{N}$ treatments). This finding is consistent with results from a whole-system nutrient-enrichment experiment in detritus-based streams (Cross et al. 2006). In our study, the positive nutrient-induced changes to leaf food quality, expressed as $\omega 3$ PUFA content, were associated with increased leaf mass loss and shredder growth. This observation adds further evidence that the nutritional quality of leaf litter can be enhanced by high-quality algae, and it appears that high-quality algae attached to leaf litter probably mediate the efficiency with which leaf litter is consumed by invertebrate shredders (Brett et al. 2009).

In our study, light intensity did not result in any significant changes in shredder growth and leaf-litter processing. This finding is probably attributable to the 2 light levels we used. Franken et al. (2005) found positive effects of light intensity on leaf mass loss and shredder growth, but they used 5 light levels, ranging from 0 to $156 \mu \mathrm{mol} \mathrm{m} \mathrm{m}^{-2} \mathrm{~s}^{-1}$. They found significant differences in the comparison of treatments with light levels $\leq 5$ and $>100 \mu \mathrm{mol} \mathrm{m}{ }^{-2} \mathrm{~s}^{-1}$. The difference between the 2 light intensities (21 and $114 \mu \mathrm{mol}$ $\mathrm{m}^{-2} \mathrm{~s}^{-1}$ ) in our study may have been too small to induce changes in algal $\omega 3$ PUFA and shredder growth.

In conclusion, our results suggest that high-quality algae attached to leaf litter regulated the FA composition and somatic growth of shredders. The presence of high-quality diatoms boosted shredder growth when nutrients were added. Invertebrate shredders may selectively allocate FA from terrestrial $\mathrm{C}$ for catabolism and retain the physiologically important FA from high-quality algae for somatic growth.

\section{ACKNOWLEDGEMENTS}

Author contributions: FG, FS, and SEB conceived and designed the experiments. FG and DV collected all samples, and FG performed the experiments. MJK conducted FA analysis for all samples. FG analyzed the data and drafted the original manuscript, and other authors provided comments and advice.

The authors thank Associate Editor Steven Francoeur and 2 anonymous referees for their valuable comments on the manuscript. The authors also thank Bob Coutts for identification of tree species, Carolyn Polson for invertebrate shredder species, 
and Ann Chuang for algal communities attached to leaf surfaces. The authors are grateful to Jing $\mathrm{Lu}$ for her assistance with field sample collection, laboratory temperature recording, and water nutrient analysis. The authors also thank Katharina Winter and Stefanie Danner for their help with lipid analysis. The research was supported by a PhD grant from Griffith University to FG.

\section{LITERATURE CITED}

Ahlgren, G., T. Vrede, and W. Goedkoop. 2009. Fatty acid ratios in freshwater fish, zooplankton and zoobenthos-are there specific optima? Pages 147-178 in M. T. Arts, M. T. Brett, and M. J. Kainz (editors). Lipids in aquatic ecosystems. Springer, New York.

Albariño, R., V. D. Villanueva, and C. Canhoto. 2008. The effect of sunlight on leaf litter quality reduces growth of the shredder Klapopteryx kuscheli. Freshwater Biology 53:1881-1889.

Allan, J. D., and M. M. Castillo. 2007. Stream ecology: structure and function of running waters. Springer Science+Business Media, Dordrecht, The Netherlands.

Brett, M. T., M. J. Kainz, S. J. Taipale, and H. Seshan. 2009. Phytoplankton, not allochthonous carbon, sustains herbivorous zooplankton production. Proceedings of the National Academy of Sciences of the United States of America 106:21197-21201.

Brett, M. T., and D. C. Müller-Navarra. 1997. The role of highly unsaturated fatty acids in aquatic foodweb processes. Freshwater Biology 38:483-499.

Bunn, S. E., P. M. Davies, and M. Winning. 2003. Sources of organic carbon supporting the food web of an arid zone floodplain river. Freshwater Biology 48:619-635.

Cargill, A. S., K. W. Cummins, B. J. Hanson, and R. R. Lowry. 1985. The role of lipids, fungi, and temperature in the nutrition of a shredder caddisfly, Clistoronia magnifica. Freshwater Invertebrate Biology 4:64-78.

Clapcott, J. E., and S. E. Bunn. 2003. Can C4 plants contribute to aquatic food webs of subtropical streams? Freshwater Biology 48:1105-1116.

Connolly, N., and R. Pearson. 2013. Nutrient enrichment of a heterotrophic stream alters leaf litter nutritional quality and shredder physiological condition via the microbial pathway. Hydrobiologia 718:85-92.

Cooney, J. J., M. M. Doolittle, O. Grahl-Nielsen, I. M. Haaland, and P. W. Kirk. 1993. Comparison of fatty acids of marine fungi using multivariate statistical analysis. Journal of Industrial Microbiology 12:373-378.

Cornut, J., V. Ferreira, A. L. Gonçalves, E. Chauvet, and C. Canhoto. 2015. Fungal alteration of the elemental composition of leaf litter affects shredder feeding activity. Freshwater Biology 60:1755-1771.

Cross, W. F., J. B. Wallace, A. D. Rosemond, and S. L. Eggert. 2006. Whole-system nutrient enrichment increases secondary production in a detritus-based ecosystem. Ecology 87:1556-1565.

Cuffney, T. F., J. B. Wallace, and G. J. Lugthart. 1990. Experimental evidence quantifying the role of benthic invertebrates in organic matter dynamics of headwater streams. Freshwater Biology 23:281-299.

Danger, M., J. Cornut, E. Chauvet, P. Chavez, A. Elger, and A. Lecerf. 2013. Benthic algae stimulate leaf litter decomposi- tion in detritus-based headwater streams: a case of aquatic priming effect? Ecology 94:1604-1613.

Desvilettes, C., G. Bourdier, C. Amblard, and B. Barth. 1997. Use of fatty acids for the assessment of zooplankton grazing on bacteria, protozoans and microalgae. Freshwater Biology 38:629-637.

Entwisle, T. J., J. A. Sonneman, and S. H. Lewis. 1997. Freshwater algae in Australia: a guide to conspicuous genera. Sainty and Associates, Sydney, Australia.

Franken, R. J., B. Waluto, E. T. Peeters, J. J. Gardeniers, J. A. Beijer, and M. Scheffer. 2005. Growth of shredders on leaf litter biofilms: the effect of light intensity. Freshwater Biology 50:459-466.

Fuller, C. L., M. A. Evans-White, and S. A. Entrekin. 2015. Growth and stoichiometry of a common aquatic detritivore respond to changes in resource stoichiometry. Oecologia (Berlin) 177:837-848.

Gladyshev, M. I., N. N. Sushchik, O. V. Anishchenko, O. N. Makhutova, V. I. Kolmakov, G. S. Kalachova, A. A. Kolmakova, and O. P. Dubovskaya. 2011. Efficiency of transfer of essential polyunsaturated fatty acids versus organic carbon from producers to consumers in a eutrophic reservoir. Oecologia (Berlin) 165:521-531.

Goedkoop, W., M. Demandt, and G. Ahlgren. 2007. Interactions between food quantity and quality (long-chain polyunsaturated fatty acid concentrations) effects on growth and development of Chironomus riparius. Canadian Journal of Fisheries and Aquatic Sciences 64:425-436.

Gooderham, J., and E. Tsyrlin. 2002. The waterbug book: a guide to the freshwater macroinvertebrates of temperate Australia. CSIRO Publishing, Collingwood, Australia.

Guo, F., M. J. Kainz, F. Sheldon, and S. E. Bunn. 2015. Spatial variation in periphyton fatty acid composition in subtropical streams. Freshwater Biology 60:1411-1422.

Guo, F., M. J. Kainz, F. Sheldon, and S. E. Bunn. 2016a. Effects of light and nutrients on periphyton and the fatty acid composition and somatic growth of invertebrate grazers in subtropical streams. Oecologia (Berlin) 181:449-462.

Guo, F., M. J. Kainz, F. Sheldon, and S. E. Bunn. 2016b. The importance of high-quality algal food sources in stream food webs-current status and future perspectives. Freshwater Biology 61:815-831.

Guschina, I. A., and J. L. Harwood. 2009. Algal lipids and effect of the environment on their biochemistry. Pages 1-24 in M. T. Arts, M. T. Brett, and M. J. Kainz (editors). Lipids in aquatic ecosystems. Springer, New York.

Heissenberger, M., J. Watzke, and M. J. Kainz. 2010. Effect of nutrition on fatty acid profiles of riverine, lacustrine, and aquaculture-raised salmonids of pre-alpine habitats. $\underline{\text { Hydro- }}$ biologia 650:243-254.

Hieber, M., and M. O. Gessner. 2002. Contribution of stream detritivores, fungi, and bacteria to leaf breakdown based on biomass estimates. Ecology 83:1026-1038.

Hötzel, G., and R. Croome. 1999. A phytoplankton methods manual for Australian freshwaters. Land and Water Resources Research and Development Corporation, Canberra, Australia.

Junk, W. J., P. B. Bayley, and R. E. Sparks. 1989. The flood pulse concept in river-floodplain systems. Canadian Special Publication of Fisheries and Aquatic Sciences 106:110-127. 
Kainz, M. J., M. T. Arts, and A. Mazumder. 2004. Essential fatty acids in the planktonic food web and their ecological role for higher trophic levels. Limnology and Oceanography 49:1784-1793.

Kainz, M. J., O. E. Johannsson, and M. T. Arts. 2010. Diet effects on lipid composition, somatic growth potential, and survival of the benthic amphipod Diporeia spp. Journal of Great Lakes Research 36:351-356.

Kainz, M. J., and A. Mazumder. 2005. Effect of algal and bacterial diet on methyl mercury concentrations in zooplankton. Environmental Science and Technology 39:1666-1672.

Kuehn, K. A., S. N. Francoeur, R. H. Findlay, and R. K. Neely. 2014. Priming in the microbial landscape: periphytic algal stimulation of litter-associated microbial decomposers. Ecology 95:749-762.

Lau, D. C., K. M. Leung, and D. Dudgeon. 2009. Are autochthonous foods more important than allochthonous resources to benthic consumers in tropical headwater streams? Journal of the North American Benthological Society 28:426-439.

Leberfinger, K., and I. Bohman. 2010. Grass, mosses, algae, or leaves? Food preference among shredders from open-canopy streams. Aquatic Ecology 44:195-203.

Manning, D. W. P., A. D. Rosemond, J. S. Kominoski, V. Gulis, J. P. Benstead, and J. C. Maerz. 2015. Detrital stoichiometry as a critical nexus for the effects of streamwater nutrients on leaf litter breakdown rates. Ecology 96:2214-2224.

McMeans, B. C., A.-M. Koussoroplis, M. T. Arts, and M. J. Kainz. 2015. Terrestrial dissolved organic matter supports growth and reproduction of Daphnia magna when algae are limiting. Journal of Plankton Research 37:1201-1209.

Mills, G. L., J V. McArthur, C. Wolfe, J. M. Aho, and R. B. Rader. 2001. Changes in fatty acid and hydrocarbon composition of leaves during decomposition in a southeastern blackwater stream. Archiv für Hydrobiologie 152:315-328.

Müller-Navarra, D. C., M. T. Brett, A. M. Liston, and C. R. Goldman. 2000. A highly unsaturated fatty acid predicts carbon transfer between primary producers and consumers. $\underline{\mathrm{Na}-}$ ture 403:74-77.

Napolitano, G. E. 1999. Fatty acids as trophic and chemical markers in freshwater ecosystems. Pages 21-44 in M. T. Arts and B. C. Wainmann (editors). Lipids in freshwater ecosystems. Springer, New York.

Napolitano, G. E., W. R. Hill, J. B. Guckert, A. J. Stewart, S. C. Nold, and D. C. White. 1994. Changes in periphyton fatty acid composition in chlorine-polluted streams. Iournal of the North American Benthological Society 13:237-249.

Nolen, J., and R. Pearson. 1993. Factors affecting litter processing by Anisocentropus kirramus (Trichoptera: Calamoceratidae) from an Australian tropical rainforest stream. Freshwater Biology 29:469-479.

Pearson, R., and N. Connolly. 2000. Nutrient enhancement, food quality and community dynamics in a tropical rainforest stream. Freshwater Biology 43:31-42.

Rier, S. T., J. M. Shirvinski, and K. C. Kinek. 2014. In situ light and phosphorus manipulations reveal potential role of biofilm algae in enhancing enzyme-mediated decomposition of organic matter in streams. Freshwater Biology 59:1039-1051.

Sargent, J., L. McEvoy, A. Estevez, G. Bell, M. Bell, J. Henderson, and D. Tocher. 1999. Lipid nutrition of marine fish during early development: current status and future directions. Aquaculture 179:217-229.

Sarnelle, O., S. Gustafsson, and L.-A. Hansson. 2010. Effects of cyanobacteria on fitness components of the herbivore Daphnia. Journal of Plankton Research 32:471-477.

Scott, J. T., J. A. Back, J. M. Taylor, and R. S. King. 2008. Does nutrient enrichment decouple algal-bacterial production in periphyton? Journal of the North American Benthological Society 27:332-344.

Stahl, P. D., and M. J. Klug. 1996. Characterization and differentiation of filamentous fungi based on fatty acid composition. Applied and Environmental Microbiology 62:4136-4146.

Suberkropp, K. 2001. Fungal growth, production, and sporulation during leaf decomposition in two streams. Applied and Environmental Microbiology 67:5063-5068.

Torres-Ruiz, M., J. D. Wehr, and A. A. Perrone. 2007. Trophic relations in a stream food web: importance of fatty acids for macroinvertebrate consumers. Iournal of the North American Benthological Society 26:509-522.

Torres-Ruiz, M., J. D. Wehr, and A. A. Perrone. 2010. Are netspinning caddisflies what they eat? An investigation using controlled diets and fatty acids. Journal of the North American Benthological Society 29:803-813.

Vannote, R. L., G. W. Minshall, K. W. Cummins, J. R. Sedell, and C. E. Cushing. 1980. The river continuum concept. Canadian Journal of Fisheries and Aquatic Sciences 37:130-137.

Wacker, A., and E. von Elert. 2001. Polyunsaturated fatty acids: evidence for non-substitutable biochemical resources in Daphnia galeata. Ecology 82:2507-2520. 